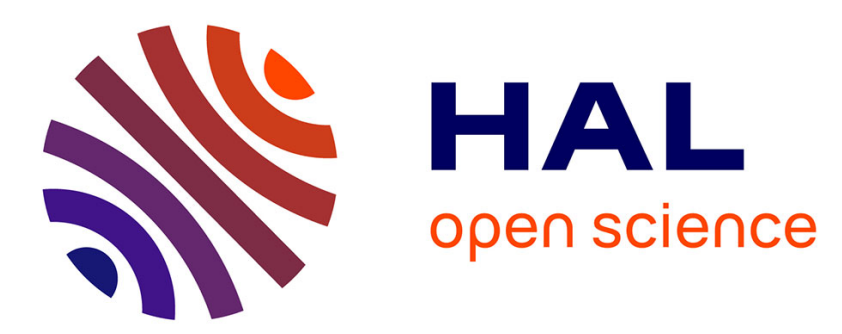

\title{
Disinfestation of historical buildings - corrosion evaluation of four fumigants on standard metals
}

Luc Robbiola, Inocencia Queixalos, Antoine Zwick, Katia Baslé, Floréal Daniel, Monique Drieux-Daguerre, Patrick J F Ducom, Jérôme Fritsch

\section{To cite this version:}

Luc Robbiola, Inocencia Queixalos, Antoine Zwick, Katia Baslé, Floréal Daniel, et al.. Disinfestation of historical buildings - corrosion evaluation of four fumigants on standard metals. Journal of Cultural Heritage, 2015, 16 (1), pp.15-25. 10.1016/j.culher.2014.02.004 . hal-01891721

\author{
HAL Id: hal-01891721 \\ https://hal.science/hal-01891721
}

Submitted on 20 Oct 2018

HAL is a multi-disciplinary open access archive for the deposit and dissemination of scientific research documents, whether they are published or not. The documents may come from teaching and research institutions in France or abroad, or from public or private research centers.
L'archive ouverte pluridisciplinaire HAL, est destinée au dépôt et à la diffusion de documents scientifiques de niveau recherche, publiés ou non, émanant des établissements d'enseignement et de recherche français ou étrangers, des laboratoires publics ou privés. 


\title{
Disinfestation of historical buildings - corrosion evaluation of four fumigants on standard metals
}

\author{
Luc Robbiola $^{\mathrm{a}, *}$, Inocencia Queixalos ${ }^{\mathrm{b}, *}$, Antoine Zwick ${ }^{\mathrm{c}}$, Katia Baslé ${ }^{\mathrm{d}}$, Floréal Daniel ${ }^{\mathrm{e}}$, \\ Monique Drieux-Daguerre ${ }^{\mathrm{f}}$, Patrick J.F. Ducom ${ }^{\mathrm{g}, \mathrm{h}}$, Jérome Fritsch ${ }^{\mathrm{g}, \mathrm{i}}$ \\ a Laboratoire TRACES (UMR 5608), université de Toulouse, CNRS, Maison de la Recherche, 5, allées A.-Machado, 31058 Toulouse cedex, France \\ b 33, rue Stalingrad, 31000 Toulouse, France \\ ${ }^{\mathrm{C}}$ CEMES-CNRS, 29, rue Jeanne-Marvig, BP 94347, 31055 Toulouse cedex 4, France \\ ${ }^{\mathrm{d}}$ Centre interdisciplinaire de conservation et restauration du patrimoine, 21, rue Guibal, 13003 Marseille, France \\ e Institut de recherche sur les archéomatériaux, UMR CNRS 5060, IRAMAT-CRPAA, université Bordeaux Montaigne, 33607 Pessac, France \\ ${ }^{\mathrm{f}}$ Laboratoire Materia Viva, 27, rue Bernard-Délicieux, 31200 Toulouse, France \\ ${ }^{\mathrm{g}}$ Laboratoire nationale d'étude des techniques de fumigation et de protection des denrées stockées, LNDS-QUALIS, 71, avenue Edouard-Bourlaux, BP 81, \\ 33883 Villenave-d'Ornon, France \\ ${ }^{\mathrm{h}}$ CaptSystèmes, 20, rue de Lormont-Village, 33310 Lormont, France \\ i Direction régionale de l'alimentation, de l'agriculture et de la forêt (DRAAF), Ministère de l'Agriculture, SRAL, antenne de Dax, 5, rue Aspremont, \\ 40100 Dax, France
}

\section{A R T I C L E I N F O}

\section{Article history:}

Received 18 March 2013

Accepted 25 February 2014

Available online 2 April 2014

\section{Keywords:}

Infestation

Fumigation

Metal

Corrosion

Methodology

Spectrocolorimetry

Electrochemistry

Raman spectroscopy

Pollutant

Methyl bromide alternatives

\begin{abstract}
A B S T R A C T
This study aims for providing adapted solutions for disinfestation of cultural buildings and collections in place of the use of methyl bromide, ozone depleting substance recently forbidden. It reports on a two-step corrosion test assessing the corrosive activity (corrosivity) of alternative fumigants. Four candidate fumigants are investigated: sulfuryl fluoride (SF), dimethyl disulfide (DMDS), phosphine $\left(\mathrm{PH}_{3}\right)$ and cyanogen (EDN) in conjunction with five standard metals: silver ( $\mathrm{Ag})$, tin ( $\mathrm{Sn})$, iron (Fe), lead $(\mathrm{Pb})$ and copper $(\mathrm{Cu})$. The applied procedure is detailed including the fumigation protocol and the description of a specific electrochemical twin cells device. The surface evolution of metallic coupons after fumigation treatments and after hygrothermal ageing $\left(35^{\circ} \mathrm{C}, 95 \% \mathrm{RH}\right)$ is compared to a blank reference series (indoor atmosphere). Results from colorimetry and electrochemical (linear sweep voltammetry) measurements, completed by Raman spectroscopy investigation show that each fumigant differently affects metals both in amplitude (amount of surface species) and in composition (nature of corrosion products). Sulfuryl fluoride (SF) can be recommended for cultural heritage but care has to be taken in presence of $\mathrm{Pb}$, Sn and $\mathrm{Cu}$. DMDS is also a good alternative candidate, however, it affects greatly $\mathrm{Cu}$ coloration and promotes $\mathrm{Pb}$ corrosion. Phosphine $\left(\mathrm{PH}_{3}\right)$ is dramatic for $\mathrm{Cu}$ and has to be avoided while the efficient biocide EDN increases corrosion of $\mathrm{Ag}$ and $\mathrm{Cu}$ even if low color variation is observed. It is strongly recommended for selecting the fumigant to properly identify the metallic artefacts prior fumigation.
\end{abstract}

\section{Research aims}

Due to the international forbidden use of methyl bromide for disinfestation of historical buildings and collections, gaseous substitutes without impact on cultural materials are required for cultural heritage applications. The objective of this work is to test alternative fumigants on standard metals, in order to evaluate the

\footnotetext{
* Corresponding authors.

E-mail addresses: robbiola@univ-tlse2.fr (L. Robbiola), iqueixalos@orange.fr (I. Queixalos).
}

global corrosive action of these fumigants according to each tested metal.

\section{Introduction}

Conservation of historical monuments can require pest control measures. Usually, the best way to reach this goal remains the prevention. It is based on a strict control of the climatic parameters linked to the storage conditions. It involves also a well-organized and strictly applied integrated pest management strategy, including for example quarantine or application of specific treatments (dynamic anoxia, thermal or ionic treatments, fumigation). 
However as recently mentioned [1], a significant increase in the presence of insect pests within historic houses is observed since this last decade probably linked to a recent increase in favourable indoor temperature conditions. As a consequence, fumigation remains an adequate method for disinfestation of large areas in which also generalized infestation of collections are observed. This treatment allows a significant and appropriate response to be applied on a large scale at ambient temperature and atmospheric pressure [2]. It allows efficient controlled mass treatments at acceptable costs and can be applied in a sealed environment either in situ or in gas-tight chamber.

Up to recently, among the gaseous fumigant applied for cultural heritage, methyl bromide $\left(\mathrm{CH}_{3} \mathrm{Br}\right)$ was one of the most widely applied. However, it has been classified by the Montreal Protocol as an Ozone Depleting Product (OPD) and its use has been phased out by January 2005. From 2007 according to Instruction 2006/140/CE, it was definitively withdrawn for biocide. Recently in March 2010, the European Community dictates its complete interdiction in agreement on the current world climate protection policy [2]. Gas alternatives to methyl bromide are required [3], fully respecting cultural materials according to good conservation practice [2].

In this context, a research program was designed to study the behaviour of four alternative fumigants preserving the ozone layer on various cultural materials $[2,4,5]$. They are sulfuryl fluoride (SF), dimethyl disulfide (DMDS), hydrogen phosphide or phosphine $\left(\mathrm{PH}_{3}\right)$ and ethane dinitrile or cyanogen (EDN), used for a broad spectrum of phytosanitary and biocide applications [3-20]. Sulfuryl fluoride (SF) [3,6-10] and hydrogen phosphide $\left(\mathrm{PH}_{3}\right)$ [3,11-13] are registered gases. These two fumigants have been already applied for cultural buildings. Sulfuryl fluoride (SF) is successfully used since 1990 [10] under Vikane ${ }^{\mathrm{TM}}$ to eliminate wood-destroying beetles in historical buildings including museums, churches and rare book libraries and also in wooden artifacts [6-10]. Dimethyl disulfide (DMDS) and ethane dinitrile (EDN) are new environmentally-safe fumigants known on control of pathogens, weeds and insects in soil [3,14-16] but not yet applied to cultural heritage. They have been considered here due to their promising possibilities including largest biocide effects and a relatively easy use application protocol. At low dose, these soil fumigants can be effective against common stored product pests according to their insecticide and fungicide properties. For DMDS, its registration as biocide is not yet achieved but is commercialized by ARKEMA Company [2]. EDN is not validated as biocide and not commercialized under a trademark. However, if the efficiency of these biocides is nowadays determined, their effects on the wide variety of cultural materials, settled or placed in the historical and cultural buildings, remain to be defined or refined. Except sulfuryl fluoride fumigant, for which a large set of studies was performed on several cultural materials such as on gilding [4,5], paper and textile [17], easel painting materials [18], protineous components like animal glue and silk $[19,20]$ or painting pigments [5,19], very little information is available for the other fumigants.

Only a few studies have been carried out on metals, revealing that the fumigants can have a corroding action. Some of them suggested caution in the use of sulfuryl fluoride (Vikane $\left.{ }^{\mathrm{TM}}\right)[6,19,21]$. Kigawa et al. tested SF on six pure metals and two copper alloys (brass and bronze) [19]. They found only a modification of optic appearance on lead and zinc. In Derrick et al. [21 and ref. therein], corrosion or tarnishing on copper, aluminium and silver, was optically observed for high RH\%. Also, interaction of SF with metallic surfaces was hypothesised to explain the decrease of the gas concentration in the sealed cell measured with IR absorption spectrometry. Phosphine $\mathrm{PH}_{3}$ severely reacts on copper and copper alloys [11-13] but not on silver, stainless steel or Pb-Sn solder [13]. For copper electronic metallic materials with $\mathrm{PH}_{3}$ concentration between 35 and $250 \mathrm{ppm}$ [13], weight variation measurements revealed that severe corrosion rates are observed both at lowest $(<25 \% \mathrm{RH})$ and highest $(>75 \% \mathrm{RH})$ relative humidity and at high temperature $\left(40^{\circ} \mathrm{C}\right)$. For DMDS and EDN, test samples of gildings applied on stones and woods have been recently investigated $[4,5]$. The results revealed that, after fumigation and ageing (thermo-hydrating cycles), gildings can be more reactive and some tarnishing can be optically detected.

Thus even if a few information regarding the global action of fumigants on cultural metals are found, a more comprehensive assessment of the impact of fumigation treatments is needed.

In the present study, the relative degree of corrosivity of the four fumigants (SF, DMDS, $\mathrm{PH}_{3}$ and $\mathrm{EDN}$ ) is determined on five standard metals $(\mathrm{Ag}, \mathrm{Sn}, \mathrm{Fe}, \mathrm{Pb}$ and $\mathrm{Cu}$ ) found in cultural heritage. Here the strategy is based on a two-step process (fumigation and ageing). Investigation was performed applying colorimetry, electrochemical linear sweep voltammetry (LSV) and Raman spectroscopy. LSV is very adapted for determining very thin corrosion layers up to $\mathrm{nm}$ size [22-25] and has been carried out using a special prototyped cell device. The results obtained on metallic coupons, before and after artificial ageing, will be then given and discussed with the purpose to find the most adapted alternative fumigant(s).

\section{Experimental}

\subsection{Materials}

\subsubsection{Gases}

Table 1 summarized the characteristics of the four selected fumigants: sulphuryl fluoride (SF), dimethyl disulfide (DMDS), hydrogen phosphide $\left(\mathrm{PH}_{3}\right)$, and ethane dinitrile (EDN). As previously introduced, these substances are known for their efficiency on insects and their relative low impact on natural environment. $\mathrm{SF}$ and $\mathrm{PH}_{3}$ have been already applied on cultural heritage while DMDS and EDN are new selected candidates. Other known efficient fumigants such as carbonyl sulfide or carbon disulfide were not considered due the insufficient data for their effective application $[2,16]$. As shown in Table 1, the toxicity of the tested fumigants is important and care for handling and using is strictly required. Their use must remain always under the control of specialists.

\subsubsection{Metals}

In order to obtain reference data on pure metallic surface, no surface treatment (oxidation or patination) was applied. Rectangular coupons of silver (Ag), tin ( $\mathrm{Sn})$, iron (Fe), lead $(\mathrm{Pb})$ and copper $(\mathrm{Cu})$ were prepared from industrial quality materials of relative high purity (>99.8 wt.\%). They were cut from clean sheets $(50 \times 20 \times 1.5 \mathrm{~mm})$, degreased and $\mathrm{SiC}$ polished up to P180 grade, then rinsed in distilled water and air dried.

\subsection{Method}

The procedure follows a two-step approach: (step 1) fumigation of metallic coupons and (step 2) exposition to harmful conservation conditions (hygrothermal exposure step). The surface characterization of coupons after step 1 brings information on the direct impact of gas and the amount of reactive species on metallic surfaces. The step 2 allows assessing the relative stability of the treated surface to high humidity and temperature exposure condition. Blank samples exposed only to indoor atmosphere (Reference gas also named Ref. here), before and after ageing, were also considered for comparison with fumigated samples.

\subsubsection{Fumigation (step 1)}

The fumigation treatments were performed according to AFNOR norms (AFNOR U 43-500/AFNOR V 30-107). They were performed 
Table 1

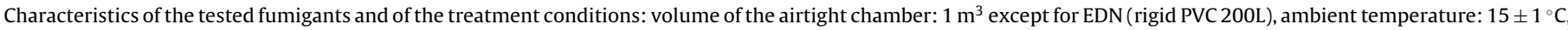
initial relative humidity: $50 \pm 5 \%$.

\begin{tabular}{|c|c|c|c|c|c|c|c|}
\hline Fumigant & $\begin{array}{l}\text { Gas } \\
\text { (formula) }\end{array}$ & $\begin{array}{l}\text { Usual and } \\
\text { commercial } \\
\text { name }\end{array}$ & $\begin{array}{l}\text { Density } \\
\text { (at } 21^{\circ} \mathrm{C} \text { ) }\end{array}$ & $\begin{array}{l}\text { Nature } \\
\text { Operating conditions } \\
\text { Exposure time (h. hour - d. day) } \\
\text { Initial injected concentration } \\
\left(\mathrm{C} \text { in } \mathrm{g} . \mathrm{m}^{-3}\right)\end{array}$ & $\begin{array}{l}\text { Effective total } \\
\text { dose }^{\mathrm{a}} \\
\text { (CTP) } \\
\text { g.h.m }{ }^{-3}\end{array}$ & $\begin{array}{l}\text { CAS registry number } \\
\text { Toxicological information } \\
\text { Exposure Standards TWA }{ }^{\mathrm{b}} \& \mathrm{STEL}^{\mathrm{c}}\end{array}$ & Remarks \\
\hline SF & $\begin{array}{l}\text { Sulfuryl } \\
\text { fluoride } \\
\left(\mathrm{SO}_{2} \mathrm{~F}_{2}\right)\end{array}$ & $\begin{array}{l}\text { ProFume }^{\mathrm{TM}} \\
\text { (also known } \\
\text { as Vikane }\end{array}$ & $\begin{array}{l}3.7 \\
(\text { atm air = 1) }\end{array}$ & $\begin{array}{l}\text { Liquefied gas under pressure } \\
\text { Injection from } 1.5 \mathrm{~L} \\
\text { cylinder - weighted with time } \\
\text { Applied with adapted filtration } \\
\text { and ventilation } \\
24 \mathrm{~h} / 150 \mathrm{~g} \cdot \mathrm{m}^{-3}\end{array}$ & 2873 & $\begin{array}{l}\text { CAS No: } 002699-79-8 \\
\text { Toxic if inhaled } \\
\text { Delayed fatal pulmonary oedema } \\
\text { possible } \\
\text { Damage to red blood cells } \\
\text { Very toxic for aquatic life } \\
\text { TWA:US: } 5 \text { ppm/EU: } 2 \text { ppm }\end{array}$ & $\begin{array}{l}\text { Rise to a } \\
\text { maximum } \\
\text { concentration } \\
\text { which } \\
\text { progressively } \\
\text { decreases } \\
\text { Registered } \\
\text { product }\end{array}$ \\
\hline DMDS & $\begin{array}{l}\text { Dimethyl } \\
\text { disulfide } \\
\left(\mathrm{CH}_{3} \mathrm{~S}-\right. \\
\left.\mathrm{SCH}_{3}\right)\end{array}$ & $\begin{array}{l}\text { DMDS } \\
\text { (Atomal }^{\mathrm{TM}} \text { ) }\end{array}$ & $\begin{array}{l}1.063 \\
(\text { water = 1) }\end{array}$ & $\begin{array}{l}\text { Liquefied gas (in a Petri dish) } \\
\text { Applied with ventilation } \\
24 \text { h/60 g.m } \text {. }^{-3}\end{array}$ & 1061 & $\begin{array}{l}\text { CAS No: } 000624-92-0 \\
\text { Toxic if inhaled } \\
\text { Irritation to eyes, skin and } \\
\text { respiratory tract } \\
\text { Very toxic for aquatic life } \\
\text { TWA (USA) } 0.5 \text { ppm as skin }\end{array}$ & $\begin{array}{l}\text { Powerful } \\
\text { insecticide, but } \\
\text { garlic smell } \\
\text { Registration in } \\
\text { progress }\end{array}$ \\
\hline $\mathrm{PH}_{3}$ & $\begin{array}{l}\text { Hydrogen } \\
\text { phosphide } \\
\left(\mathrm{PH}_{3}\right)\end{array}$ & Phosphine & $\begin{array}{l}1.14 \\
(\mathrm{~atm}=1)\end{array}$ & $\begin{array}{l}\text { Solid AlP pellets } \\
7 \text { days } / 2 \mathrm{~g} \cdot \mathrm{m}^{-3}(10 \text { pellets of } \\
\left.0.2 \mathrm{~g} \cdot \mathrm{m}^{-3}\right)\end{array}$ & $227^{\mathrm{d}}$ & $\begin{array}{l}\text { CAS No: } 007803-51-2 \\
\text { Highly toxic by inhalation } \\
\text { Irritation to the respiratory tract, } \\
\text { lung irritation, chess tightness } \\
\text { Delayed fatal pulmonary oedema } \\
\text { possible } \\
\text { STEL: US ( } 1 \mathrm{ppm} \text { ), EU: } 0.3 \mathrm{pmm} \\
\text { TWA:US:0.3 ppm//EU: } 0.1 \mathrm{ppm}\end{array}$ & $\begin{array}{l}\text { More exposure } \\
\text { time, due to its } \\
\text { specific } \\
\text { conditioning } \\
\text { Registered } \\
\text { product }\end{array}$ \\
\hline EDN & $\begin{array}{l}\text { Ethane } \\
\text { dinitrile } \\
\left(\mathrm{C}_{2} \mathrm{~N}_{2}\right)\end{array}$ & $\begin{array}{l}\text { Cyanogen } \\
\text { (Viton }{ }^{\mathrm{TM}} \text { ) }\end{array}$ & $\begin{array}{l}1.806 \\
(\mathrm{~atm}=1)\end{array}$ & $\begin{array}{l}\text { Gas introduced with a } 2 \mathrm{~L} \\
\text { Hamilton syringe (air purged at } \\
\text { the opposite side) } \\
\text { Applied with ventilation } \\
24 \mathrm{~h} / 200 \mathrm{~g}^{-3} \mathrm{~m}^{-3}\end{array}$ & 3041 & $\begin{array}{l}\text { CAS No: } 000460-19-5 \\
\text { May cause irritation to the } \\
\text { respiratory tract } \\
\text { Hazardous to the aquatic } \\
\text { environment } \\
\text { TWA: } 10 \text { ppm }\end{array}$ & $\begin{array}{l}\text { Colourless gas, } \\
\text { close to } \\
\text { almond smell } \\
\text { Insecticide and } \\
\text { fungicide } \\
\text { Not registered }\end{array}$ \\
\hline
\end{tabular}

\footnotetext{
a Concentration Time Product or CTP: concentration of fumigant in (g.m $\mathrm{m}^{-3}$.hour).

b Time Weighted Average (TWA) 8 or 10 hours.

c Short-Term Exposure Limits (STEL) 15 minutes from US National Institute for Occupational Safety and Health (NIOSH).

d Calculated value from the curve integration of Fig. $1 \mathrm{~b}$.
}

in gas-tight stainless steel fumigation chambers of $1 \mathrm{~m}^{3}$ for SF, DMDS and $\mathrm{PH}_{3}$, and carried out in a rigid PVC chamber of $0.2 \mathrm{~m}^{3}$ for EDN. The exposure conditions are summarized in Table 1. The chambers were located in air conditioned room with a maintained temperature of $15 \pm 1{ }^{\circ} \mathrm{C}$ and $\mathrm{RH} 50 \pm 5 \%$.

The injection mode of each gas in the chamber was conducted according to their physical properties. SF was introduced in the chamber as a liquid under pressure contained into a cylinder (dose 150 g.m ${ }^{-3}$ ). For $\mathrm{PH}_{3}$, solid $\mathrm{PH}_{3}$ pellets of aluminium phosphide reacting with water vapor were used (dose $2 \mathrm{~g} \cdot \mathrm{m}^{-3}$ ). For DMDS, liquid DMDS was placed in a Petri dish (dose 60 g.m $\mathrm{m}^{-3}$ ). EDN gas was injected with a 2 L Hamilton syringe while air was being purged from the opposite side (dose $200 \mathrm{~g} \cdot \mathrm{m}^{-3}$ ). The exposure time was 24 hours for SF, DMDS and EDN and 7 days for $\mathrm{PH}_{3}$. SF fumigation has been performed through calcium carbonate particles to avoid gas impurities and acid effect on cultural materials [4,5,9]. During the fumigations with SF, DMDS and $\mathrm{PH}_{3}$, a fan was permanently applied for gas homogenization inside the chamber. The Concentration Time Product (CTP) (Table 1) was determined in g.hour. $\mathrm{m}^{-3}$, except for phosphine where the only rule was to be over $200 \mathrm{ppm}$ at anytime [26]. CTP allows a good appreciation of the gas remaining free during fumigation. It was determined from the free fumigant concentration, monitored by thermoconductivity (Fumiscope apparatus) for SF, DMDS and EDN and by using an electrochemical cell for $\mathrm{PH}_{3}$ (Oldham MX2100 Industrial Scientific).

The evolution of gas concentration with time is given in Fig. 1 and shows that sorption is very small with SF and very high with
EDN. Due to its heavier specific weight, initial vaporisation of DMDS was very slowly up to 6 hours before reaching a constant concentration. Phosphine hydrolysis is slow likely due to the initial $50 \% \mathrm{RH}$ in the chamber. The gas evolutions here applied to cultural heritage well agree to those recommended for good commercial fumigations [26].

\subsubsection{Hygrothermal exposure (step 2)}

In order to test the stability of the surface compounds after fumigation, a continuous six days artificial ageing with $\mathrm{RH}=95 \%$ and $\mathrm{T}=35^{\circ} \mathrm{C}$ was performed. The metallic samples were put vertically and located in the middle of the ageing chamber (Votsch apparatus). Here this simple hygrothermal ageing test is equivalent to the Oddy's test, as defined in Green and Thickett [27], applied to metallic cultural artefacts for testing evolution of surface species in indoor environment. It is relatively severe for iron, lead and copper which are more sensible to humidity variation than silver and tin as mentioned in European norm NF EN ISO 11844-1:8-2008 (table C1).

\subsection{Surface characterization}

The characterization of surface was performed after step 1 and after step 2, for fumigated samples as well as for blank samples only exposed to Reference gas (indoor atmosphere without fumigation). All the quantitative results are expressed as an average of at least three measurements on each metallic coupon. 

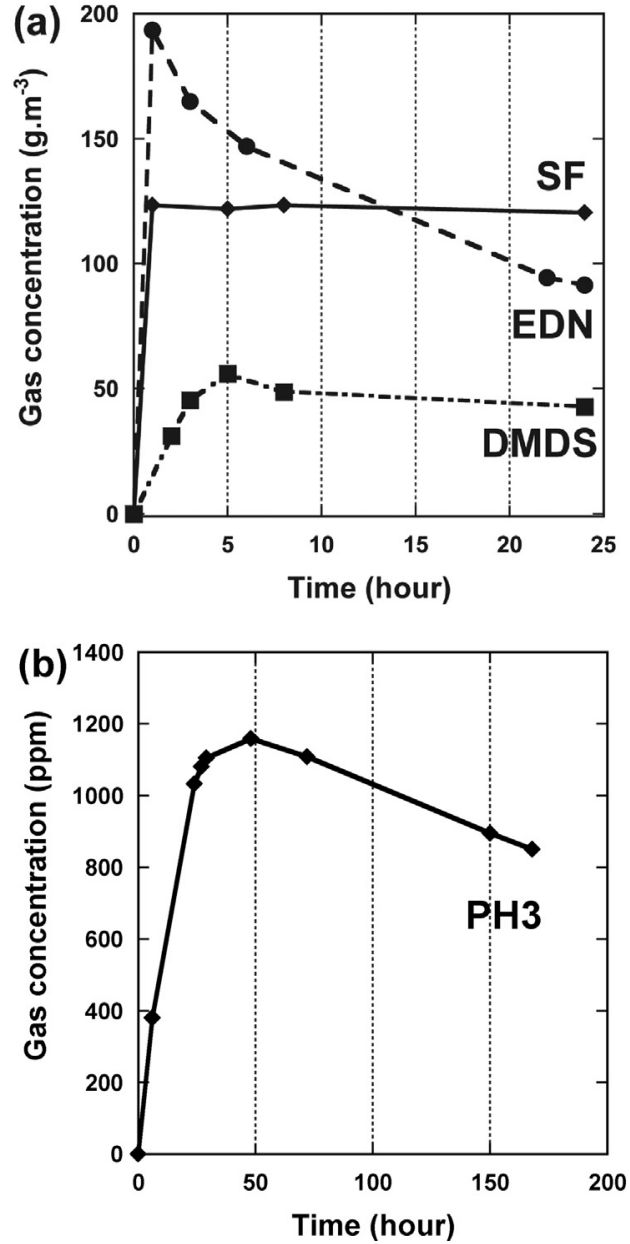

Fig. 1. Evolution of gas concentration during fumigation of metallic coupons: (a) for initial dosages of 150 g.m $\mathrm{m}^{-3}$ for SF, $60 \mathrm{~g} . \mathrm{m}^{-3}$ for DMDS and $200 \mathrm{~g} . \mathrm{m}^{-3}$ for EDN and (b) $2 \mathrm{~g} \cdot \mathrm{m}^{-3}(1400 \mathrm{ppm})$ for $\mathrm{PH}_{3}$.

\subsubsection{Spectrocolorimetry}

Colorimetric measurements of the metal surfaces were performed in order to determine variations such as tarnishing or more pronounced alteration $[28,29]$. This provides a fast assessment regime to screen the action of fumigants. A HunterLab portable spectrophotometer (Miniscan XE Plus 4000S) operating under standard daylight illuminant D65 $\left(10^{\circ}\right.$ observation angle, $400-700 \mathrm{~nm}$ spectral range, $10 \mathrm{~nm}$ resolution, $6 \mathrm{~mm}$ analyzed area diameter) was used. The results are expressed according to the CIELAB color reference space. In this representation, each color is defined by three coordinates: $a^{*}$ and $b^{*}$ corresponding to different color hues and $L^{*}$ to lightness ranging from black to white. For each measured surface coupon, the color variation $\Delta E^{*}$ $\left(\Delta E^{*}=\left(\Delta L^{*}+\Delta a^{*}+\Delta b^{*}\right)^{1 / 2}\right)$ was determined from the color of the non corroded surface measured after initial polishing. A variation of $\Delta E^{*} \leq \pm 3$ is usually nearly indiscernible for human eyes and indicates that no significant visual impact of the treatment shall be reported.

\subsubsection{Electrochemical reduction}

Electrochemical reduction was performed applying linear sweep voltammetry (LSV). In this aim, a specific electrochemical device has been developed (Fig. 2). As depicted in Fig. 2a, two cells made with an inert polymer are placed in a device which allows moving cell 1 up to cell 2 . The metallic coupon is vertically sandwiched between the twin cells, allowing analysis of both coupon
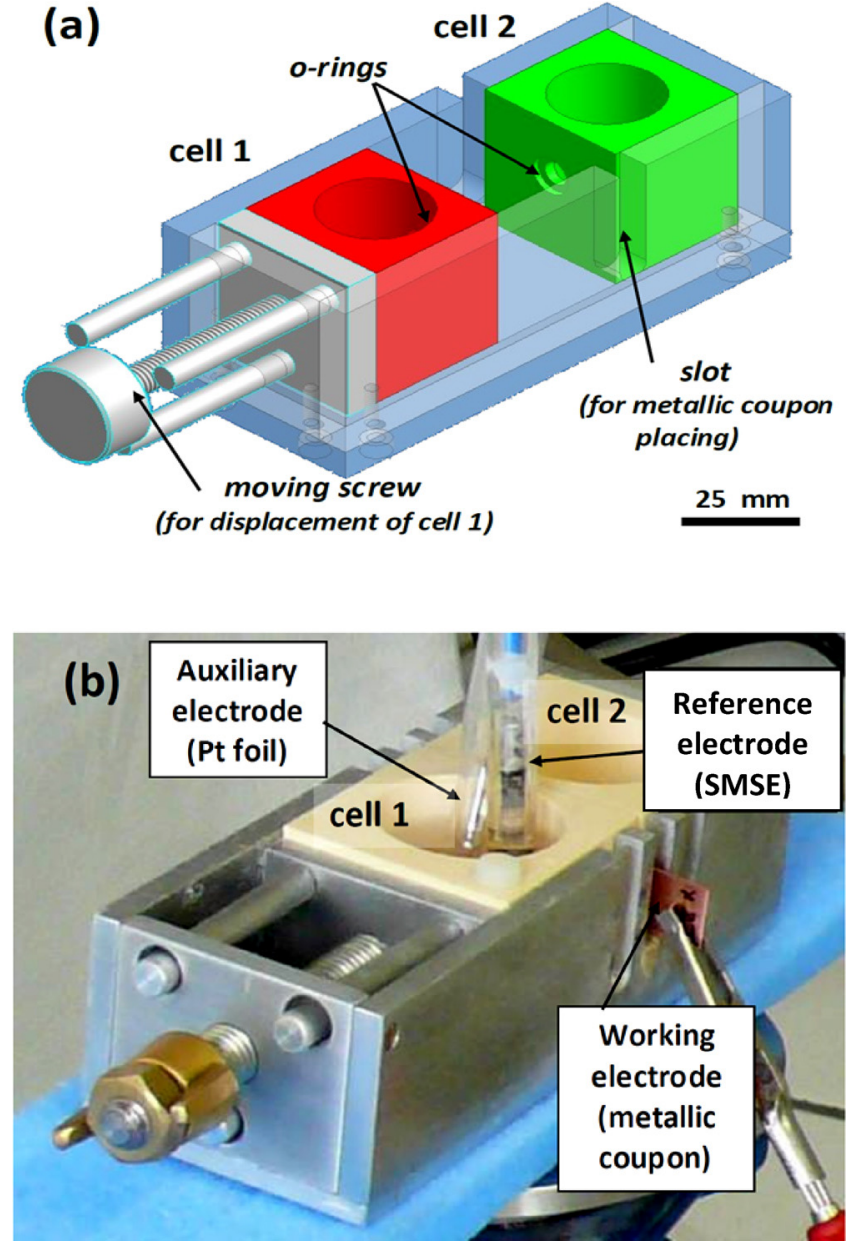

Fig. 2. Electrochemical cell experimental set-up: (a) twin cells prototype (open system - without metallic coupon) and (b) operating device (close system - the metallic coupon is vertically blocked within the two cells).

sides with a constant area $\left(S=0.196 \mathrm{~cm}^{2}\right)$ on all measurements (Fig. 2b).

A three-electrode electrochemical system was used: the metallic coupon as working electrode, a saturated sulfate mercurous electrode (SMSE: $\mathrm{K}_{2} \mathrm{SO}_{4}$ saturated $\mathrm{Hg} / \mathrm{HgSO}_{4},+0.65 \mathrm{~V}$ vs. NHE at $\left.25^{\circ} \mathrm{C}\right)$ as reference and a platinum foil $\left(0.5 \mathrm{~cm}^{2}\right)$ as auxiliary electrode. Experiments were carried out with a Solartron 1280B potentiostat controlled with Solartron CorrWare software, also used for the evaluation of the reduction charge $Q\left(\mathrm{C}_{\mathrm{cm}} \mathrm{cm}^{-2}\right)$ :

$Q=J . t$

with J: current density (A.cm ${ }^{-2}$ ) and $t$ : sweep time (s).

Selected aqueous electrolytes are:

- $\mathrm{NaNO}_{3}(0.1 \mathrm{M})$ for $\mathrm{Ag}$, Sn and Fe;

- $\mathrm{NaC}_{2} \mathrm{H}_{3} \mathrm{O}_{2} .2 \mathrm{H}_{2} \mathrm{O}(0.1 \mathrm{M})$ for $\mathrm{Cu}$;

- $\mathrm{Na}_{2} \mathrm{CO}_{3}, \mathrm{NaHCO}_{3} .2 \mathrm{H}_{2} \mathrm{O}(0.1 \mathrm{M}$ ) for $\mathrm{Pb}$ (sodium sesquicarbonate $0.1 \mathrm{M})$.

All reagents were from analytical grade. For each experiment, $10 \mathrm{~cm}^{3}$ of aerated electrolyte was used. In most cases, the effects due to the reduction of dissolved dioxygen, which may partially mask reduction peaks, were overcome. The reduction current density-potential $(J-E)$ curves were performed in potentiodynamic mode at $v=5 \mathrm{mV} . \mathrm{s}^{-1}$ from the open-circuit potential obtained after one minute in the electrochemical solution. No correction of the ohmic drop was applied. On each $(J-E)$ curve, the total charge $Q$ was 
determined from the integration of the reduction peaks, after subtraction of the baseline defined by the tangent from the beginning of the peak up to its end in the more cathodic region.

The total reduced electrical charge $Q$ per surface unit is related to the amount of corrosion components formed on the metal surface [22-25,30]. Higher is the absolute value of $Q$, more amount of electrospecies is formed on the surface and more is the fumigant corrosive. The thickness of the corrosion film, $e(\mathrm{~nm})$, on the metal surface can be approximated applying the Faraday's law (Eq. (2)) assuming that the distribution of the species is uniform at the surface:

$e=M_{A} \cdot Q \cdot 10000 / n_{A} \cdot F \cdot \rho_{A}$

with $e$ : film thickness (nm), $M_{A}$ : molar mass of A species (g), $Q$ is the total reduction charge of A species $\left(\mathrm{mC} . \mathrm{cm}^{-2}\right), n_{A}$ electron number (cation valency) involved in the reduction of $A, F$ Faraday constant (96485 C. $\left.\mathrm{mol}^{-1}\right)$ and $\rho_{A}$ density of A species $\left(\mathrm{g} . \mathrm{cm}^{-3}\right)$.

Thus for typical oxides in atmospheric condition $\left(\mathrm{Ag}_{2} \mathrm{O}, \mathrm{SnO}_{2}\right.$, $\mathrm{FeO}, \mathrm{PbO}$ and $\left.\mathrm{Cu}_{2} \mathrm{O}[25,30,31]\right)$, for a reduced charge $Q$ of $1 \mathrm{mC} \cdot \mathrm{cm}^{-2}$, the film thickness on pure metals is around $1 \mathrm{~nm}\left(\approx 0.6 \mathrm{~nm}\right.$ for $\mathrm{SnO}_{2}$ and $\mathrm{FeO}, 1.2 \mathrm{~nm}$ for $\mathrm{PbO}$ and $\mathrm{Cu}_{2} \mathrm{O}$ and $1.7 \mathrm{~nm}$ for $\left.\mathrm{Ag}_{2} \mathrm{O}\right)$.

\subsubsection{Raman spectroscopy}

The Raman spectra were performed in order to determine the surface species. Measurements were carried out only on the coupons after ageing with a Jobin Yvon Dilor XY apparatus (Ar: $488 \mathrm{~nm}, 0.3 \mathrm{~mW}$, LabSpec software) on selected areas of $\approx 5 \mu \mathrm{m}$ spot size. The scan number and the accumulation time (usually $60 \mathrm{~s}$ ) were adapted according to the intrinsic signal intensity.

Although Raman spectroscopy is a very sensitive method well adapted to the characterization of the oxidized metallic surfaces, spectrum processing was remaining difficult mainly due to the very low thickness or poor crystallization of the surface compounds even after ageing. The results are roughly reproducible at the micrometric level despite the relative homogeneity of the corroded surfaces pointed out by electrochemical reduction for $\mathrm{Ag}$ or $\mathrm{Sn}$ as it will be reported later. $\mathrm{PH}_{3}$ investigation will only concern $\mathrm{Cu}$ coupons, which dramatically react with.

Often systematic carbonyl pollution with characteristic bands at about $1600 \mathrm{~cm}^{-1}$ corresponding to graphitic carbon and at $2930 \mathrm{~cm}^{-1}$ for $\mathrm{C}-\mathrm{H}$ stretching vibrations was detected more particularly on silver.

\section{Results and discussion}

Here, two aspects are addressed. The first one involves the global action of fumigants and their corrosivity on the metallic coupons. The second aspect relates to the behaviour of metal surfaces before and after ageing, also investigating in more details the surface nature applying electroreduction (LSV) and Raman spectroscopy.

\subsection{Corrosivity of fumigants}

The colorimetric measurements and the determination of the amount of reduced charge of the tested coupons are given in Figs. 3 and 4 respectively. In these figures, the mean values of the evolution of surface colors (color differences $\Delta E^{*}$ ) and of $Q$ values $\left(\mathrm{mC} . \mathrm{cm}^{-2}\right)$ are given for the different fumigants, before (step 1$)$ and after the ageing test (step 2). Indoor atmosphere exposure is used as a blank reference for comparison and is named "Reference" (Ref.) in Figs. 3 and 4.

In indoor atmospheric condition, a slight tarnishing is systematically observed on metals which increases the color difference values after ageing as shown in Fig. 3. This is related to the formation of a thin corrosion film for which the thickness can be
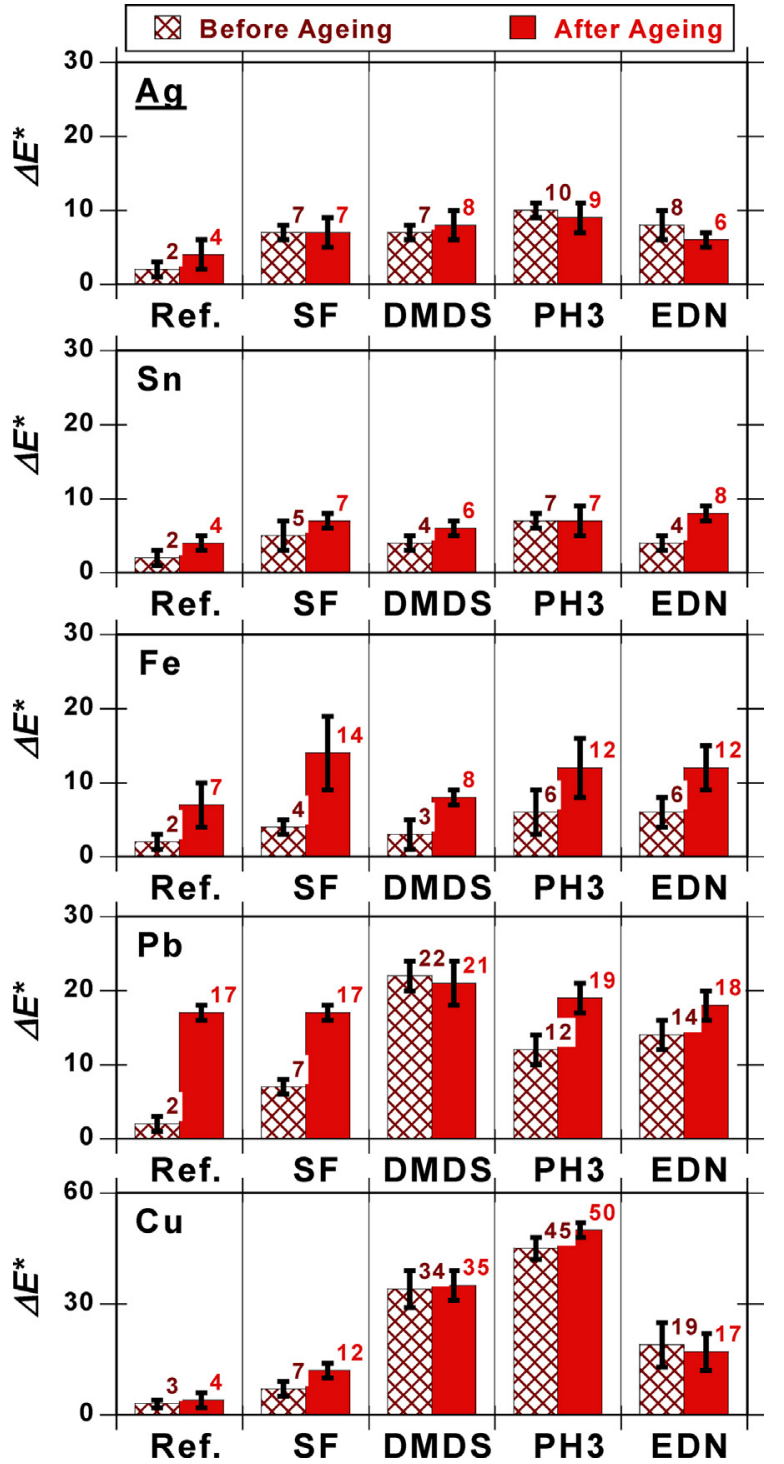

Fig. 3. Color difference $\left(\Delta E^{*}\right)$ of metallic coupons ( $\mathrm{Ag}, \mathrm{Sn}, \mathrm{Fe}, \mathrm{Pb}, \mathrm{Cu}$ ) with applied gas treatments. before (left) and after (right) ageing for 6 days at $35^{\circ} \mathrm{C}$ and $95 \% \mathrm{RH}$. Ref.: blank indoor atmosphere (no fumigation), SF: $\mathrm{SO}_{2} \mathrm{~F}_{2}$, DMDS: $\mathrm{CH}_{3} \mathrm{~S}-\mathrm{SCH}_{3}, \mathrm{PH}_{3}$ : phosphine, EDN: $\mathrm{C}_{2} \mathrm{~N}_{2}$.

estimated between 1 to $10 \mathrm{~nm}$, according to the Faraday's law (Eq. (2)) applying the $Q$ (Ref.) values given in Fig. 4.

Except a few cases later discussed, a similar evolution between colorimetry and surface electroreduction measurements is observed for fumigated coupons. This is particularly well illustrated for $\mathrm{Fe}$ and $\mathrm{Pb}$ in Figs. 3 and 4, widely affected by the ageing step, as revealed by a marked increase of both their colour variation and amounts of reduced species.

Regarding the action of fumigants from Figs. 3 and 4, the comparison with the results of the blank indoor atmosphere (Ref.) reveals that after the two-step process:

- SF is comparable to the indoor atmosphere. Both $\Delta E^{*}$ and $Q$ values are close to those obtained for the blank Ref. series for all the metals, except for $\mathrm{Pb}$ slightly more reactive (mean of electroreduced species $Q=307$ instead of $235 \mathrm{mC} . \mathrm{cm}^{-2}$ for Ref. series);

- DMDS markedly affects $\mathrm{Pb}\left(Q=490\right.$ instead of $235 \mathrm{mC} . \mathrm{cm}^{-2}$ for Ref. series) and Cu colour variation $\left(\Delta E^{*}=35\right.$ instead of 4 for Ref. series), even if it reveals good performance for $\mathrm{Ag}$, Sn and Fe; 


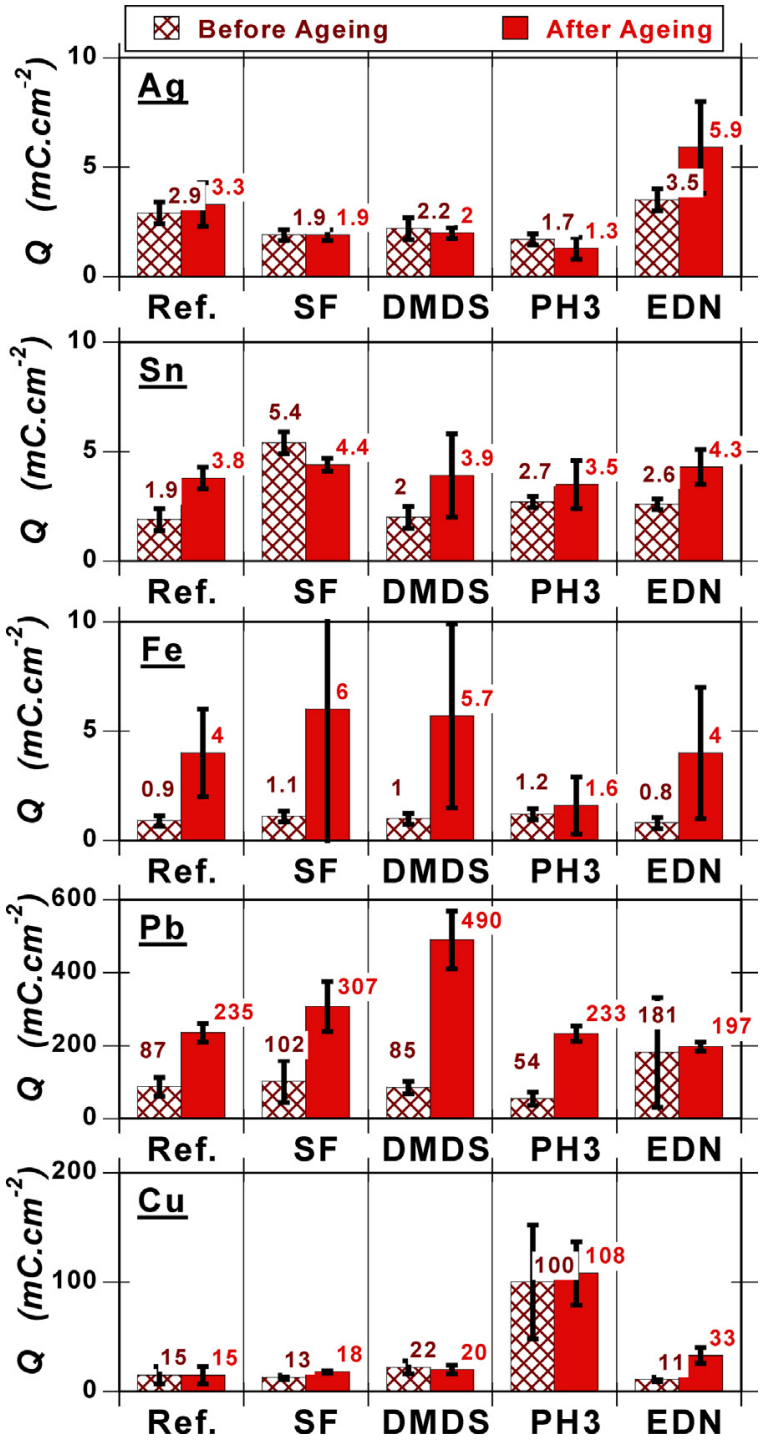

Fig. 4. Total reduction charge $Q\left(\mathrm{mC} . \mathrm{cm}^{-2}\right)$ related to the amount of surface species formed after gas treatments of metallic coupons ( $\mathrm{Ag}, \mathrm{Sn}, \mathrm{Fe}, \mathrm{Pb}, \mathrm{Cu}$ ), before (left) and after (right) ageing for 6 days at $35^{\circ} \mathrm{C}$ and $95 \% \mathrm{RH}$. Ref.: blank indoor atmosphere, SF: $\mathrm{SO}_{2} \mathrm{~F}_{2}$, DMDS: $\mathrm{CH}_{3} \mathrm{~S}-\mathrm{SCH}_{3}, \mathrm{PH}_{3}$ : phosphine, EDN: $\mathrm{C}_{2} \mathrm{~N}_{2}$.

- EDN acts similarly to blank indoor atmosphere. However, it significantly modifies the Cu colour (colour variation $\Delta E^{*}=17$ instead of 4 for Ref. series) and increases the formation of surface products on $\mathrm{Ag}$ and $\mathrm{Cu}\left(Q=5.9\right.$ and $33 \mathrm{mC} . \mathrm{cm}^{-2}$ respectively, instead of 3.3 and $15 \mathrm{mC} . \mathrm{cm}^{-2}$ for Ref. series);

- $\mathrm{PH}_{3}$ exhibits a dramatic behaviour for copper: a thick layer of blue cupric species is observed optically, inducing a very important colour deviation ( $\Delta E^{*}=50$ instead of 4 for Ref. series) as well as an increase of the total reduction charge $(Q=108$ instead of $15 \mathrm{mC} . \mathrm{cm}^{-2}$ for Ref. series). But except on $\mathrm{Cu}$, the overall action of $\mathrm{PH}_{3}$ appears apparently similar to that of blank indoor atmosphere. Even more, $\mathrm{PH}_{3}$ could inhibit pure $\mathrm{Ag}$ corrosion as a marked decrease of the average $Q$ values is observed $\left(Q=1.3 \mathrm{mC} . \mathrm{cm}^{-2}\right.$ with $\mathrm{PH}_{3}$ instead of $3.3 \mathrm{mC} . \mathrm{cm}^{-2}$ for Ref. series).

Thus a classification of the fumigant corrosivity after ageing remains uncertain as each fumigant differently affects the tested metals. For example, DMDS is found to be very corrosive towards $\mathrm{Pb}$ but poorly affects $\mathrm{Ag}$, while the converse is true for EDN. As a consequence, a more detailed analysis of the treated surfaces is required for a better assessment of the fumigant action on each tested metal.

\subsection{Relationship between colour deviation $\Delta \mathrm{E}^{*}$ and surface charge Q}

Even if the overall evolution of the color deviation values (Fig. 3) is accompanied by a similar evolution of the electroreduced charges (Fig. 4), a few specific cases has to be mentioned for which color difference $\Delta E^{*}$ and charge $Q$ are not linked together.

Firstly, as revealed for EDN on silver ( $\mathrm{Ag}$ ), an important increase of electroreduced species $Q$ can be detected while color modification $\Delta E^{*}$ is very low compared to blank indoor atmosphere (Ref). Thus, pronounced corrosion can occur even if the color remains poorly modified. On the opposite, a marked color modification can be evidenced with no significant increase of $Q$. This is the case for DMDS on $\mathrm{Cu}$ (before and after ageing) or on $\mathrm{Pb}$ (before ageing), for EDN on $\mathrm{Cu}$ (before ageing) and for $\mathrm{PH}_{3}$ on $\mathrm{Fe}$ (after ageing). Here, the fumigation induces a marked color evolution without pronounced corrosion.

An important point has to be noticed at this stage. In fact, even if colorimetry remains an interesting method to screen the surface evolution impacted by pollutants, the use of more developed methods must be applied for assessing properly the fumigated metals.

\subsection{Overall corrosion behaviour of metals}

A more informative approach on the behaviour of treated metals is given when are considered both the mean total reduction charge $Q$ values as well as their standard deviation $\sigma_{Q}$. $Q$ value gives information on the corrosion amplitude: higher $Q$ values indicate more developed corrosion. $\sigma_{Q}$ brings information on the surface homogeneity: higher $\sigma_{Q}$ value relates to more heterogeneous corroded surface.

This is depicted in the Fig. 5 for all the studied metals after ageing (step 2). Distinctive quadrants can be defined according to specific corrosion domains: passivation (or uniform corrosion) for low $Q$ and low $\sigma_{Q}$ (thin film of a few $\mathrm{nm}$ ), localised corrosion for low $Q$ and high $\sigma_{Q}$ and generalised corrosion for high $Q$ (thick film) and high $\sigma_{Q}$.

Fig. 5 confirms the different corrosion behaviour of metals observed after ageing:

- silver (Ag) and tin (Sn) are poorly reactive metals. The applied fumigants induce a rather uniform corrosion corresponding to a tarnishing of a few nm thick (cf. 3.3.2), except EDN on Ag and also DMDS on Sn here inducing surface heretogeneity (higher $\sigma_{Q}$ values);

- markedly more reactive to fumigants are iron (Fe), lead $(\mathrm{Pb})$ and copper $(\mathrm{Cu})$ metals:

o for Fe, localised corrosion is linked to the specific formation of brown rust systematically observed as later confirmed by Raman spectroscopy,

o for $\mathrm{Pb}$ and $\mathrm{Cu}$, generalized corrosion is clearly observed. It is dramatic for $\mathrm{Pb}$ with DMDS and for $\mathrm{Cu}$ with $\mathrm{PH}_{3}$.

According to each metal, from Fig. 5 also and by comparison to the reference (blank indoor atmosphere), it can be concluded that the most aggressive fumigants are: EDN on silver (Ag), DMDS on tin ( $\mathrm{Sn}$ ) in a less extent, SF and DMDS on lead ( $\mathrm{Pb}$ ), $\mathrm{PH}_{3}$ and EDN (in a less extent) on copper $(\mathrm{Cu})$.

\subsection{Surface characterization}

Another important aspect to consider is the stability of fumigated surfaces after hygrothermal ageing (step 2). This allows to 


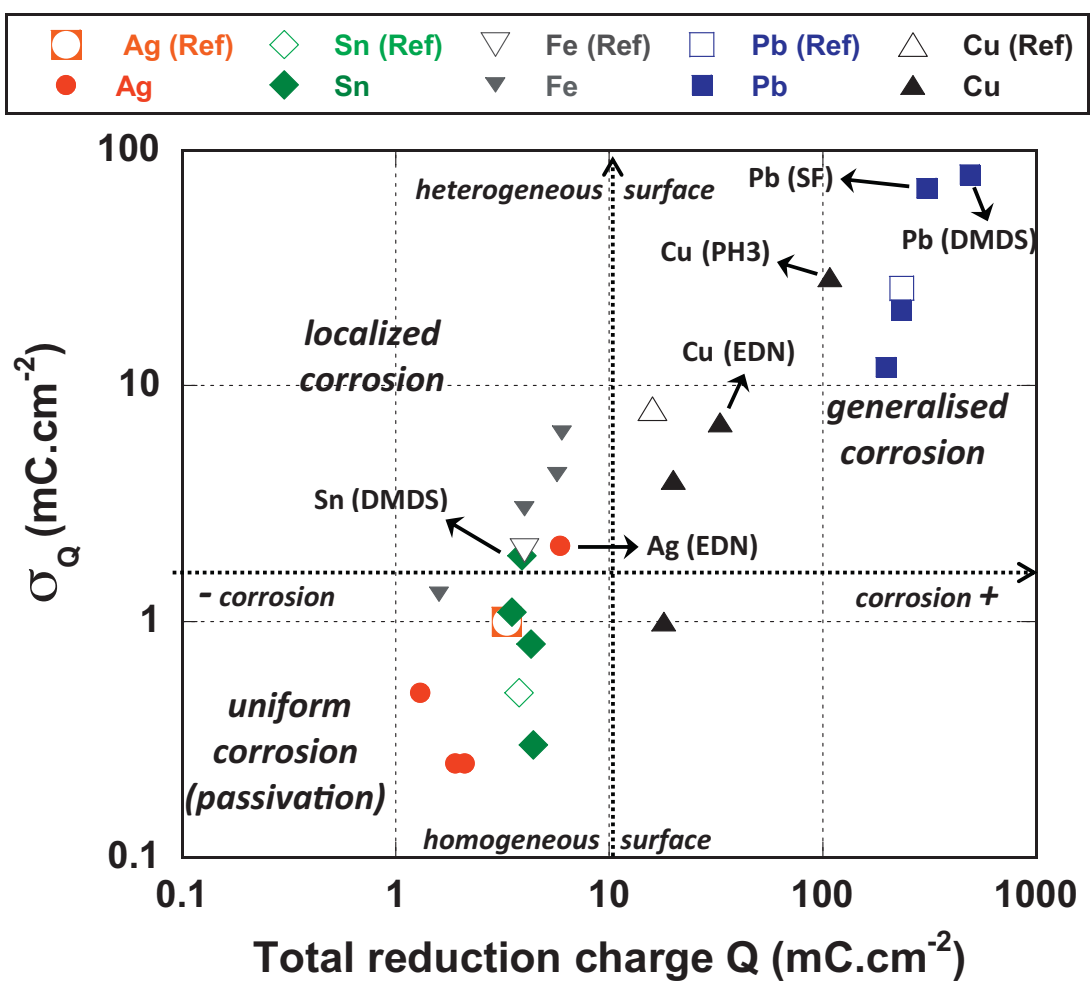

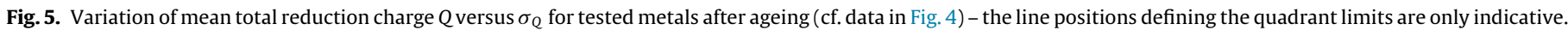
(Ref) corresponds to blank indoor atmosphere (without applied fumigant).

see if exposure to high RH\% induces the evolution of surface compounds but also to discern if these compounds could be directly linked to specific chemical species induced by the applied fumigant. In this last case, fumigant could act as a specific pollutant.

\subsubsection{Less reactive metals $\mathrm{Ag}$ and $\mathrm{Sn}$}

For the less reactive metals silver and tin, ageing of fumigated coupons poorly affects their surfaces. A comparison of the reduction $(J-E)$ curves, before and after ageing, is shown in Fig. 6. Except the cases of EDN on Ag and SF on Sn hereafter discussed, the general shape of the $(J-E)$ curves is poorly modified. A difference of behaviour between these two metals is however revealed: Ag surfaces appear sensitive to the gas treatment applied while, for $\mathrm{Sn}$, the fumigated surfaces exhibit important similarities with the blank indoor atmosphere. For silver (Ag) as shown in Fig. 6, several reduction peaks are formed. For blank Reference, SF, DMDS and EDN the reduction peak maximum at $-0.9 \mathrm{~V} / \mathrm{MSE}$ could be ascribed to $\mathrm{Ag}_{2} \mathrm{O}$, while the peak at about $-1.2 \mathrm{~V} / \mathrm{MSE}$ could be probably related to $\mathrm{Ag}_{2} \mathrm{~S}$ for SF, DMDS and EDN [22,30]. Also the peak at $-0.6 \mathrm{~V} / \mathrm{MSE}$ has to be linked more likely to an unknown compound related to $\mathrm{PH}_{3}$. For the $\mathrm{Sn}$ coupons except with SF gas, one reduction peak is found at about $-1.55 \mathrm{~V} / \mathrm{MSE}$ relative to tin dioxide systematically found in atmospheric condition [31].

In Fig. 6, the specific cases of EDN on silver $(\mathrm{Ag})$ and SF on tin (Sn) are clearly revealed. The shape of their reduction curves is modified with ageing. This indicates an evolution of the surface compounds which changed of nature with hygrothermal test. For EDN on silver (Ag), a specific product at around $-0.45 \mathrm{~V}$ is observed but vanished after ageing, while two others peaks appear at around $-0.6 \mathrm{~V}$ and $-1.2 \mathrm{~V} / \mathrm{MSE}$. It can be stated that the initial product linked to EDN fumigation is unstable with humidity and temperature and enhanced the corrosion of silver. For SF on tin (Sn), a peak observed at -1.48 is shifted to $-1.6 \mathrm{~V} / \mathrm{MSE}$. Interestingly here is the decrease of the $Q$ value, which could indicate that the tin-compound initially formed with SF became more protective with the hygrothermal ageing.

Representative Raman spectra on silver (Ag) coupons are shown Fig. 7. The identification of silver oxides and sulphides was difficult, as the surface compounds often exhibit a photosensitive behaviour inducing photo-decomposition even at low laser power [32]. This was more manifest for Ag coupons submitted to SF and EDN fumigants. However in Fig. 7, low frequency bands between 150 and $250 \mathrm{~cm}^{-1}$, related to $\mathrm{Ag}$ lattice modes in $\mathrm{Ag}-\mathrm{O}$ are evidenced. Most often systematic carbonyl pollution in atmosphere, with characteristic bands at about $1600 \mathrm{~cm}^{-1}$ corresponding to graphitic carbon and at $2930 \mathrm{~cm}^{-1}$ for C-H stretching vibrations was detected particularly on silver. For Sn coupons, attempts to observe regular Raman spectra of Sn surface species failed. Except for EDN on Sn for which broad bands at around 550 and $3565 \mathrm{~cm}^{-1}$ were observed (spectra not shown). These bands can be assigned respectively to Sn-O and $\mathrm{O}-\mathrm{H}$ symmetric stretching vibrations linked to nano- or poorly crystallized "hydroxylated" tin oxide [33], in accordance with the above electrochemical result.

\subsubsection{More reactive metals $\mathrm{Fe}, \mathrm{Pb}$ and $\mathrm{Cu}$}

Regarding the reactive metals (Fe, $\mathrm{Pb}$ and $\mathrm{Cu}$ ), surface characterization coupling electrochemical reduction and Raman spectroscopy were performed.

Pure iron remains very sensible to localized attacks with rust formation after hygrothermal exposure. The electrochemical curves reveal poorly resolved reduction peaks at around $-1.55 \mathrm{~V} / \mathrm{MSE}$, not illustrated here. These very broad peaks are probably linked to the presence of iron hydroxy-oxide and/or iron oxide as revealed by Raman spectroscopy for DMDS and EDN fumigants (Fig. 8).

For blank Reference and SF series, only broad poorly resolved bands centered at around $340 \mathrm{~cm}^{-1}$ are observed (spectra not shown) but are difficult to ascribe to specific vibrations. For DMDS (Fig. 8) and also SF, a broad band between $680-710 \mathrm{~cm}^{-1}$ is detected. This can be probably ascribed to disordered maghemite 

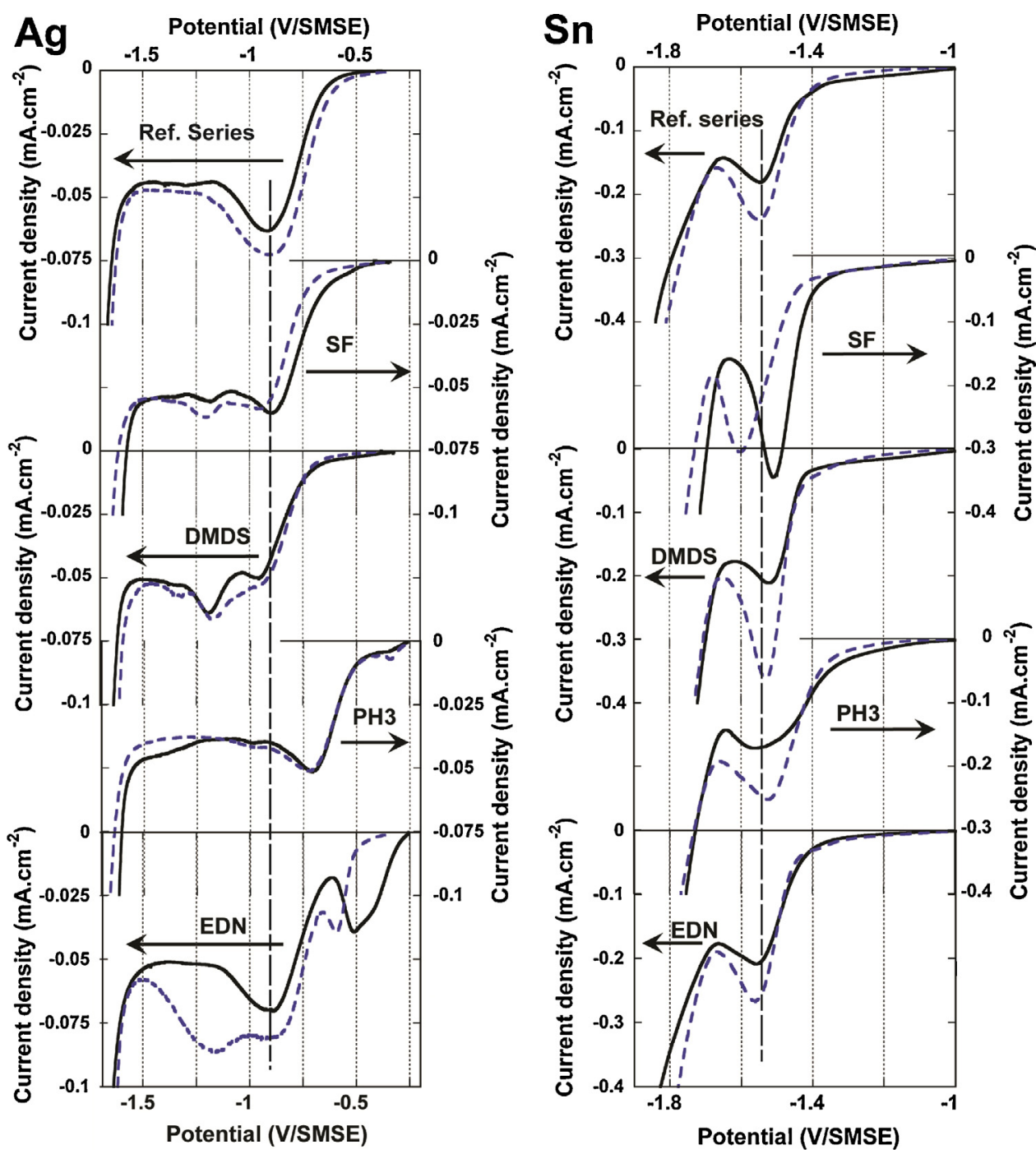

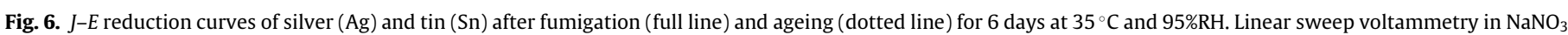
$0.1 \mathrm{M}$ aqueous solution.

$\gamma-\mathrm{Fe}_{2} \mathrm{O}_{3}$ or a mixture of this phase with ferrhydrite $\left(\mathrm{Fe}_{2} \mathrm{O}_{3} \cdot \mathrm{H}_{2} \mathrm{O}\right)$ as also found on ancient iron artefacts [33,34]. Only the surface submitted to EDN treatment showed partially crystallized lepidocrocite $(\gamma$-FeOOH$)$ with bands at $235,365,525,640$ and $1300 \mathrm{~cm}^{-1}$ similar to the one identified by De Faria et al. [34] but accompanied by a band at around $1070 \mathrm{~cm}^{-1}$ relative to carbonate anion.

A difference of electrochemical behaviour between lead and copper is observed. The general shape of the reduction curves remains feebly affected after hygrothermal exposure, except for DMDS and EDN on $\mathrm{Cu}$, and even if an increase in current density is often observed. In Fig. 9, the electrochemical reduction $(J-E)$ curves are given only for $\mathrm{Pb}$ and $\mathrm{Cu}$ aged coupons. $\mathrm{PH}_{3}$ fumigant curve with a broad peak only was not reported here for $\mathrm{Cu}$ being one order of magnitude higher than those found for the other fumigants.

For $\mathrm{Pb}$ coupons, broad and overlapped peaks are observed while $\mathrm{Cu}$ coupons exhibit more resolved and sharp peaks. The poorly resolved reduction peaks initialising from $-1.0 \mathrm{~V}$ are relative to a thick corrosion layer, which includes $\mathrm{Pb}$ (II) compounds such as $\mathrm{PbO}$ (litharge) and also probably cerussite and hydrocerussite as confirmed by Raman investigation in Fig. 8. For Reference series, Raman spectra reveal the presence of litharge ( $\mathrm{PbO}$ ) with a strong band at about $150 \mathrm{~cm}^{-1}$, very similarly to lead coupons exposed to atmosphere during 24 months as detailed in Bernard et al. [35, sample
PP1]. For SF, DMDS and EDN fumigants (Fig. 8), a mixture of litharge (litharge $\mathrm{PbO} \approx 145-150$ (vs), 280 and $330 \mathrm{~cm}^{-1}$ ) with sometimes cerussite and/or hydrocerussite $\mathrm{PbCO}_{3}$ at $1050-1055 \mathrm{~cm}^{-1}$ including a broad $\mathrm{OH}$ symmetric stretching band $\left(3570 \mathrm{~cm}^{-1}\right)$ is detected.

For copper $(\mathrm{Cu})$, different nature of surface species are revealed according to the applied fumigants, indicating a direct action of these fumigants on the surface product formation. As shown Fig. 9, the reduction of the aged blank coupons confirms the presence of different cuprous oxides (peaks at about -1.1 and more pronounced around $-1.5 \mathrm{~V} / \mathrm{MSE}$ ), in good accordance with usual values on copper [ 25 and ref. therein]. For SF and even more for EDN, these peaks are also observed but more pronounced at $-1.1 \mathrm{~V} / \mathrm{MSE}$. For DMDS fumigant, a supplementary reduction peak around $-1.3 \mathrm{~V} / \mathrm{MSE}$ could be possibly linked to the specific formation of sulphide species [25].

Raman spectra on aged $\mathrm{Cu}$ coupons are given Fig. 10 confirming the presence of cuprous oxide (specific main bands at 195-215 and $630 \mathrm{~cm}^{-1}$ [36]). For DMDS, no supplementary band linked to sulphide is observed but it must be recalled that numerous copper sulphides such as $\mathrm{Cu}_{2} \mathrm{~S}$ (chalcocite) don't exhibit any vibration band. For EDN, a supplementary but not ascribed band at $460 \mathrm{~cm}^{-1}$ is observed. The Raman results confirm the different copper surface species previously expected from electrochemical investigation. Finally for $\mathrm{PH}_{3}$, additional vibration bands (Fig. 10) 


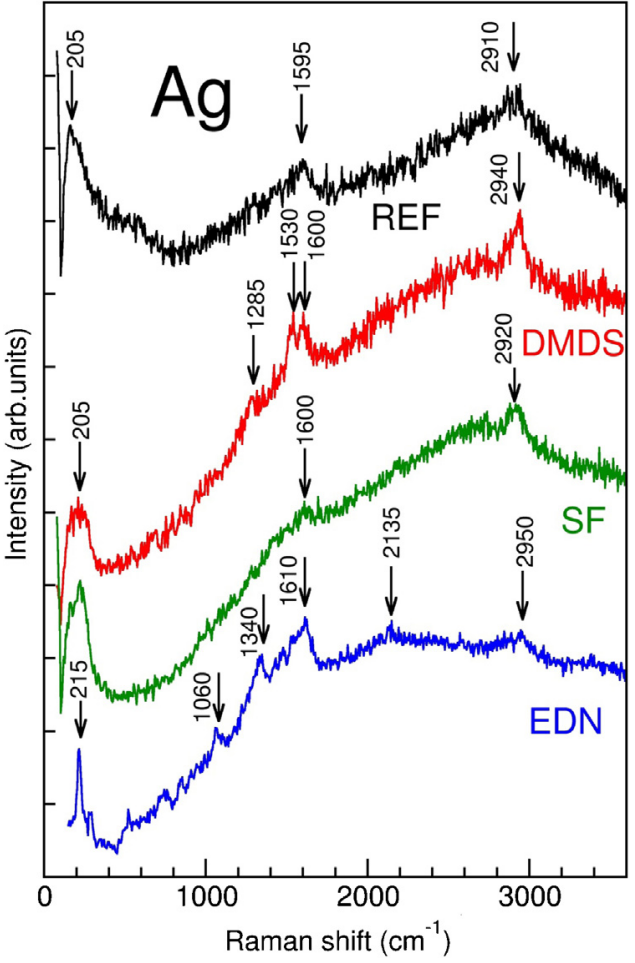

Fig. 7. As measured Raman spectra of silver $(\mathrm{Ag})$ coupons after ageing ( $488 \mathrm{~nm}, \mathrm{Ar}$ laser, $0.3 \mathrm{~mW}$ ).

well confirm the drastic corrosivity of this fumigant on copper. It induces the formation of both carbonate and phosphate species. Cupric carbonate is revealed by the bands at 1355 and $1590 \mathrm{~cm}^{-1}$ (assigned to carbonate anti symmetric stretching) while a small broad band at $3250-3400 \mathrm{~cm}^{-1}$ is linked to hydroxyl symmetric

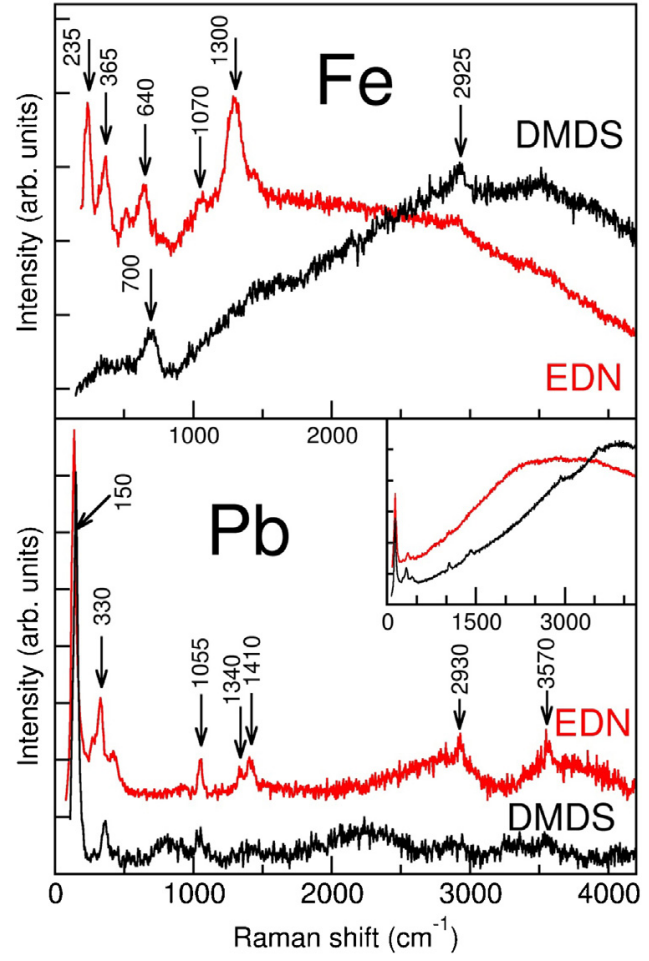

Fig. 8. Raman spectra of iron ( $\mathrm{Fe}$ ) and lead $(\mathrm{Pb})$ coupons after ageing (DMDS and EDN fumigation). Upper part and Inset: raw spectra ( $488 \mathrm{~nm}$, Ar laser, $0.3 \mathrm{~mW})$. Lead coupons spectra (lower part) are background subtracted.

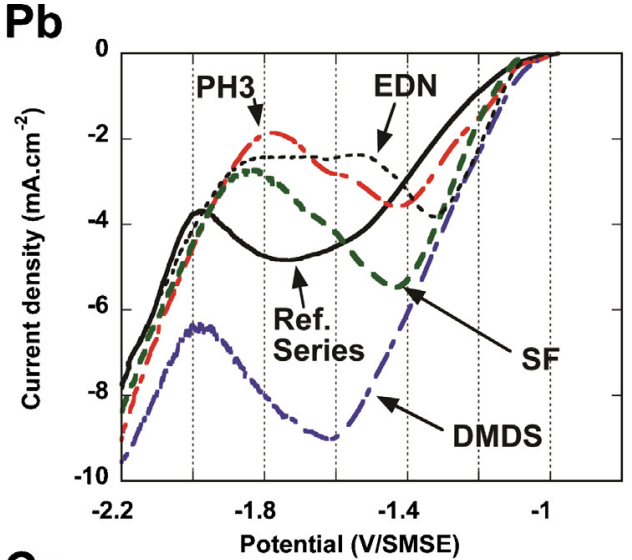

$\mathrm{Cu}$

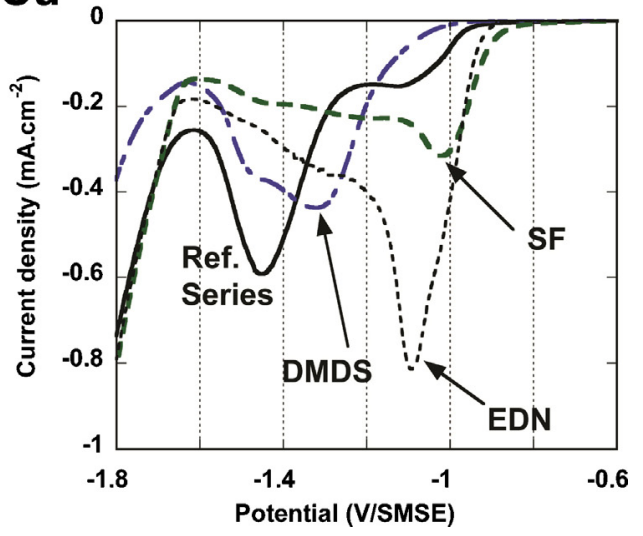

Fig. 9. $J-E$ reduction curves of lead $(\mathrm{Pb})$ and copper $(\mathrm{Cu})$ after fumigation and ageing. Linear sweep voltammetry in aqueous solution with sodium sesquicarbonate for $\mathrm{Pb}\left(\mathrm{Na}_{2} \mathrm{CO}_{3}, \mathrm{NaHCO}_{3} .2 \mathrm{H}_{2} \mathrm{O}-0.1 \mathrm{M}\right)$ and with sodium acetate for $\mathrm{Cu}$ $\left(\mathrm{NaC}_{2} \mathrm{H}_{3} \mathrm{O}_{2} \cdot 2 \mathrm{H}_{2} \mathrm{O}-0.1 \mathrm{M}\right)$.

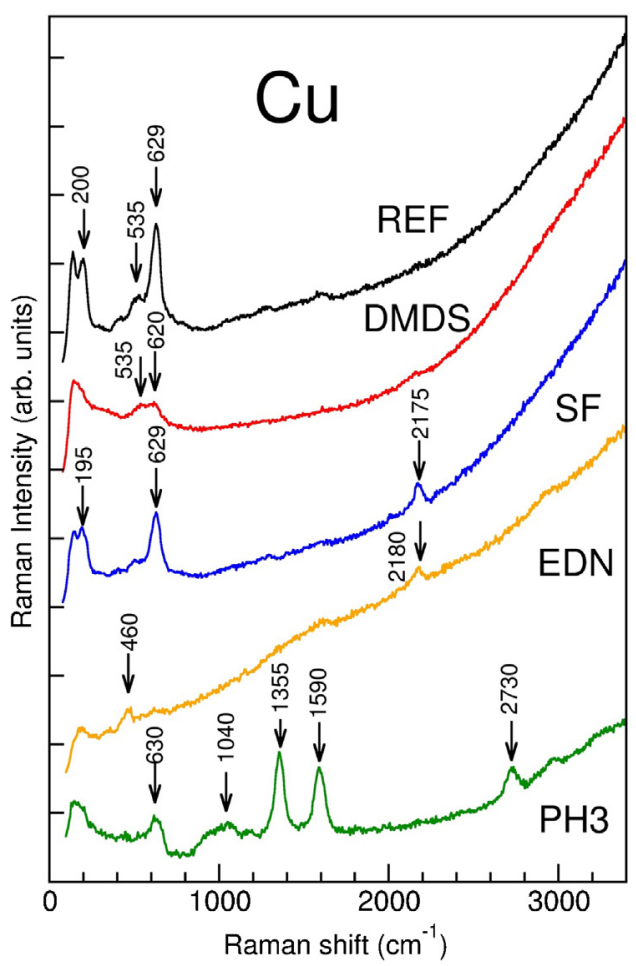

Fig. 10. As measured Raman Spectra of aged copper $(\mathrm{Cu})$ coupons ( $488 \mathrm{~nm}$, Ar laser, $0.3 \mathrm{~mW})$. 
stretching [36]. Vibrations around $1040 \mathrm{~cm}^{-1}$ (broad band between $950-1060 \mathrm{~cm}^{-1}$ ) could be ascribed to poorly crystallised phosphate products, quite similar to libethenite $\mathrm{Cu}_{2} \mathrm{PO}_{4} \mathrm{OH}$ or pseudomalachite $\mathrm{Cu}_{5}\left(\mathrm{PO}_{4}\right)_{2}$ [36, p.156-158]. The presence of phosphate compounds on Cu well agrees with previous results [13] for which important amounts of $\mathrm{P}$ and $\mathrm{O}$ elements from EDS analysis were found after $36 \mathrm{~h}$ fumigation with $\mathrm{PH}_{3}(250 \mathrm{ppm})$.

\subsubsection{Fumigant reaction on metallic surface}

Additional information to identification of surface species has to be noticed. Rarely mentioned in the literature, this concerns the adsorption of fumigant on metallic surface. Previous infrared experiments performed with $\mathrm{SF}$ on $\mathrm{Ag}$ and $\mathrm{Cu}$ in sealed cell [21] have shown that significant gas adsorption could be expected on the metallic surfaces. Furthermore (Table 1), a remnant odor of garlic and almond remains from coupons respectively treated with DMDS and EDN. However, no specific vibration bands of fumigants were identified on aged metals. No specific spectral features were recorded for sulfuryl fluoride for which the main Raman shift is the SF stretching vibration band at $884-888 \mathrm{~cm}^{-1}$ (antisymmetric $\mathrm{SF}_{2}$ mode) [37]. Also no indication of high concentration of adsorbed DMDS molecules were found according to the lack of the S-S stretching band around $500 \mathrm{~cm}^{-1}$ [38] and of the aliphatic C-S symmetric stretching band between $670-700 \mathrm{~cm}^{-1}$ as observed on silver or gold metals [39]. On the same way, bands of the $v_{1}$ $\left(2330 \mathrm{~cm}^{-1}\right)$ and $v_{2}\left(845 \mathrm{~cm}^{-1}\right)$ fundamental vibrations for EDN fumigant [40] have not been recorded and $\mathrm{PH}_{3}$ (liquid state) Raman frequencies at $979 \mathrm{~cm}^{-1}, 1110 \mathrm{~cm}^{-1}$ and $2306 \mathrm{~cm}^{-1}$ [41] are not present on $\mathrm{Cu}$ coupons. At this stage, no supposed adsorbed fumigant molecules were thus evidenced here.

Nevertheless, dissociation of fumigant molecules undergoing specific surface reaction is found. This is the case for $\mathrm{PH}_{3}$ on copper as depicted in Fig. 10. For EDN fumigant, a gas impact is also observed. For silver treated with EDN, small sharp bands for M-CN and $\mathrm{CN}$ vibrations respectively at $300-350$ and $2135 \mathrm{~cm}^{-1}$ [42] are present (Fig. 7), probably linked to the unattributed reduction peak found at about $-0.6 \mathrm{~V} / \mathrm{MSE}$ (Fig. 6). In the same way, with EDN on $\mathrm{Cu}$ (Fig. 10), the band at $2180 \mathrm{~cm}^{-1}$ could be assigned to $\mathrm{C}-\mathrm{N}$ vibration. Additionally, for $\mathrm{Sn}$ (spectrum not shown) and $\mathrm{Pb}$ (spectrum Fig. 8) exposed to EDN, a sharp band at $1035-1055 \mathrm{~cm}^{-1}$ assigned to $\mathrm{N}-\mathrm{O}$ symmetric stretching vibration is assigned to nitrate species revealing that $\mathrm{C}_{2} \mathrm{~N}_{2}$ decomposition occurred on metallic surface; here EDN acting as a pollutant inducing specific corrosion.

\section{Conclusions}

This study focused on methyl bromide alternatives for preservation of historic buildings and cultural collections. It covers the determination of the corrosiveness of four fumigants on five standard metals applying a two-step protocol, involving the use of a set of complementary surface characterization techniques (colorimetry, linear sweep voltammetry and Raman spectroscopy). It has been shown that the corrosive action of the fumigation treatment varies both in amplitude and in composition with the tested metals.

By comparison to blank indoor atmosphere used as a reference series, silver (Ag) and tin (Sn) are poorly reactive and developed very thin corrosion film. On the opposite iron $(\mathrm{Fe})$, lead $(\mathrm{Pb})$ and copper $(\mathrm{Cu})$ are more reactive. Furthermore for $\mathrm{Sn}$ and $\mathrm{Fe}$, the limited reduction peak reveals that the surface species are not so different from the untreated samples submitted to indoor atmospheric environment. On the converse, for $\mathrm{Ag}, \mathrm{Cu}$ and $\mathrm{Pb}$, the important number of reduction peaks indicate the presence of several species but also a relative complexity of the corrosion phenomena.
Taking into account the different impacts obtained on each metal, it can be concluded on the relative corrosiveness of applied fumigants that:

- sulphuryl fluoride (SF) seems the most suitable substitution gas to methyl bromide. However, SF induces the formation of specific surface products on lead, tin and copper also slightly affecting its color;

- dimethyl disulfide (DMDS) could give satisfactory results except its very persistent garlic smell and its negative effects on lead. It accelerates noticeably the tarnishing on lead and copper linked to the formation of different surface species;

- hydrogen phosphide $\left(\mathrm{PH}_{3}\right)$ gives satisfactory results except on copper where irreversible dramatic effects are observed. On other metals, $\mathrm{PH}_{3}$ promotes the formation of stable compounds which seems to limit the corrosion on silver $(\mathrm{Ag})$ and on iron $(\mathrm{Fe})$. Thus, in spite of its easy application, it must be prohibited for the disinfestation of heritage premises when copper metal artefacts (or copper alloys) are present;

- cyanogen (EDN) significantly affects silver and copper linked to the formation of specific surface compounds. However it appears to promote stabilization of lead.

It has been shown that fumigant can act as a pollutant involved in the formation of specific corrosion products. More investigation is required on their chemical identification and on their stability with time.

Finally, a clear identification of metallic artefacts prior fumigation is strongly recommended for selecting the fumigant to be applied.

\section{Acknowledgements}

We thank Pr Virginia Costa who conceptualized the electrochemical twin cells and its application for cultural heritage. We wish also to acknowledge A. Creteau and R. Flammang from ENSCParis (Chimie Paris-Tech) for manufacturing the prototype and S. Badosa and B.Clergue for their appreciated cooperation. The authors thank the referees for their contribution.

\section{References}

[1] P. Brimblecombe, P. Lankester, Long-term changes in climate and insect damage in historic houses, Stud. Conserv. 58 (2013) 13-22.

[2] K. Baslé, Traitements de désinsectisation des biens patrimoniaux: législation et critères méthodologiques, in: La lettre de l'OCIM - Conservation préventive : quels traitements pour les collections, 138, 2011, pp. 24-30.

[3] P.J.F Ducom, The return of the fumigants, in: 9th International Working Conference on Stored Product Protection, Oct 2006, KPS6-2, 2006, pp. 510-516 http://bru.gmprc.ksu.edu/proj/iwcspp/pdf2/9/kps62.pdf

[4] F. Daniel, K. Baslé, A. Mounier, I. Queixalos, L. Robbiola, Gas substitutes for methyl bromide in cultural heritage disinfestation of historical monuments, J. Entomol. Acarol. Res., Ser. II 43 (2011) 211-227.

[5] F. Daniel, K. Baslé, A. Mounier, I. Queixalos, L. Robbiola, P. Ducom, Y. Ciesla, J. Fritsch, The disinfestation of historical monuments: gas substitutes for methyl bromide, in: S. Navarro, H.J. Banks, D.S. Jayas (Eds.), 9th international CAF conference "Controlled atmosphere and Fumigation in Stored Products", Antalya, Turkey, 2012, pp. 222-230.

[6] M.R. Derrick, H.D. Burgess, M.T. Baker, N.E. Binnie, Sulfuryl fluoride (vikane): review of its use as a fumigant, J. Am. Inst. Conserv. 29 (1990) 77-90.

[7] N.-Y. Su, Efficacy of Sulfuryl Fluoride against selected insect pest of museums, in: Proceedings of the 2nd International Conference on Biodeterioration of cultural property, Oct. 1992, Yokohama, Japan, 1992, pp. 434-439.

[8] S. Prabhakaran, Commercial performance and global development status of ProFume ${ }^{\circledR}$ gas fumigant, in: 9th International Working Conference on Stored Product Protection, Oct 2006, PS6-19-6259, 2006, pp. 635-641 http://bru.gmprc.ksu.edu/proj/iwcspp/pdf2/9/6259.pdf

[9] G. Binker, J. Binker, G. Fröba, Vikane ${ }^{\circledR}$ and its use as a fumigant for artefacts in Europe, J. Entomol. Acarol. Res., Ser. II 43 (2011) 229-235.

[10] G. Binker, Report on the first fumigation of a church in Europe using sulfury fluoride, in: Proc.1st Int. Conf. on insect pests in the urban environment, 30 June-3 July 1993, Cambridge, UK, 1993, pp. 51-55. 
[11] E.J. Bond, T. Dumas, S. Hobbs, Corrosion of metals by the fumigant phosphine, J. Stored Prod. Res. 20 (1984) 57-63.

[12] R. Bertholon, Corrosion of copper and copper alloys during disinfection treatment by fumigation with phosphine, in: Actes de la 7th rencontre annuelle Section métal ICOM-SFIIC, 23 April 1993, Draguignan, France, 1993, pp. 1-13 (ISBN 2-906375-01-2).

[13] R.J. Brigham, Corrosive effects of phosphine, carbon dioxide, heat and humidity on electronic equipment, Canadian Leadership in the Development of Methyl Bromide Alternatives, Ottawa Canada, Aug. 1998, 46 p. https://www. cytec.com/specialtychemicals/PDFs/AgriculturalFumigation/ph3corr1.pdf

[14] J. Fritsch, A. Baudry, T. Aubert, DMDS as a new potential alternative to methyl bromide for soil disinfestations, in: Proc. Int. Conf. on alternatives to methyl bromide, March 2002, Seville-SP, P 340, 2002, pp. 321-327.

[15] P. Charles, DMDS: a new alternative for soil disinfestations, in: 2003 Annual Int. Research Conf. on Methyl Bromide Alternatives and Emissions Reductions (Mbao), San Diego, 2003 (4 p. 23) http://mbao.org/2003/023 \%20charlespmbao\%20san\%20diego\%20atofina.pdf

[16] R. Ryan, N. Grant, J. Nicolson, D. Beven, A. Harvey, Sterigas ${ }^{\mathrm{TM}}$ and Cosmic ${ }^{\mathrm{TM}}$ update on proposed new fumigants, in: 9th International Working Conference on Stored Product Protection, Fumigation and Control Atmosphere, Oct. 2006, PS6-17-6165, 2006, pp. 624-629 http://bru.gmprc.ksu.edu/proj/ iwcspp/pdf2/9/6165.pdf

[17] H.D. Burgess, N.E. Binnie, The Effect of VikaneTM on the Stability of Cellulosic and Ligneous Materials - Measurement of Deterioration by Chemical and Physical Methods, in: 1990 MRS Spring Meeting. MRS Proceedings Symposium G, 185, 1990, p. 791 (8 pp.)

[18] R.J. Koestler, E. Parreira, E.D. Santoro, P. Noble, Visual effects of selected biocides on easel painting materials, Stud. Conserv. 38 (1993) 265-273.

[19] R. Kigawa, Y. Miyazawa, M. Koizumi, C. Sano, S. Miura, H. Nochide, H. Kimura, B. Tomita, Evaluation of the effects of various pest-controlling reagents on pigments and metals: effects of pesticides, fumigants, carbon dioxide and nitrogen [in Japanese], Bunkazai Hozon-Syuhuku Gakkaisi 43 (1999) 12-21.

[20] R. Kigawa, T. Strang, N. Hayakawa, N. Yoshida, H. Kimura, G. Young, Investigation of effects of fumigants on proteinaceous components of Museum objects (muscle, animal glue and silk) in comparison with other non-chemical pest eradication measures, Stud. Conserv. 56 (2011) 191-215.

[21] M.R. Derrick, D. Stulik, M. Landry, Infrared Spectroscopy in Conservation Science, J.P. Getty Trust - Getty Conservation Inst. Ed, 1999, pp. 155-159.

[22] V. Costa, Impact of environmental conditions on metallic artefacts from the treasure rooms of Reims Cathedral, in: Heritage, Weathering and Conservation, Fort, Alvarez de Buergo, Gomez-Heras \& Vasquez-Calvo Eds, Vol. 1, 2006, pp. 453-456.

[23] A. Domenech-Carbo, M.T. Domenech-Carbo, V. Costa, Electrochemical Methods, in: F. Scholz (Ed.), Archaeometry, Conservation and Restoration, Springer, 2009, pp. 121-138.

[24] A. Domenech-Carbo, M.T. Domenech-Carbo, M.A. Peiro-Ronda, L. OseteCortina, Application of modified Tafel analysis to the identification of corrosion products on archaeological metals using voltammetry of microparticles, Electroanalysis 23 (2011) 2803-2812.
[25] T.M. Tran, C. Fiaud, E.M.M. Sutter, A. Villanova, The atmospheric corrosion of copper by hydrogen sulphide in underground conditions, Corros. Sci. 45 (2003) 2787-2802.

[26] P. Ducom, Lutte contre les insectes par gazage: aspect réglementaire, types de gaz, contrôles d'efficacité, in: Biodétérioration et désinfection des collections d'archives et de bibliothèques, Actes $2^{\mathrm{e}}$ journées Conservation Préventive. 18-19 Nov. 1996, Arles, France, 1999, pp. 112-126.

[27] L.R. Green, D. Thickett, Testing materials for use in the storage and display of antiquities: a revised methodology, Stud. Conserv. 40 (1995) 145-152.

[28] E. Franceschi, P. Letardi, G. Luciano, Colour measurements on patinas and coating system for outdoor bronze monuments, J. Cult. Herit. 7 (2006) $166-170$.

[29] S. Goidanich, L. Toniolo, S. Jafarzadeh, I.O. Wallinder, Effects of wax-based anti-graffiti on copper patina composition and dissolution during four years of outdoor urban exposure, J. Cult. Herit. 11 (2010) 288-296.

[30] M.C. Bernard, E. Dauvergne, M. Evesque, M. Keddam, H. Takenouti, Reduction of silver tarnishing and protection against subsequent corrosion, Corros. Sci. 47 (2005) 663-679.

[31] S. Jouen, B. Hannoyer, O. Piana, Non-destructive surface analysis applied to atmospheric corrosion of tin, Surf. Interface Anal. 34 (2002) 192-196.

[32] I. Martina, R. Wiesinger, D. Jembrih-Simbürger, M. Schreiner, Micro-Raman characterisation of silver corrosion products: instrumental set up and reference database, e-Preserv. Sci. 9 (2012) 1-8.

[33] M.C. Bernard, S. Joiret, Understanding corrosion of ancient metals for the conservation of cultural heritage, Electrochim. Acta 54 (2009) 5199-5205.

[34] D.L.A. de Faria, S.V. Silva, M.T.D. Oliveira, Raman micro spectroscopy of some iron oxides and oxyhydroxides, J. Raman Spectrosc. 28 (1997) 873-878.

[35] M.C. Bernard, V. Costa, S. Joiret, Assessing indoor lead corrosion using Raman spectroscopy during electrochemical reduction, e-Preserv. Sci. 6 (2009) $101-106$.

[36] V. Hayez, Use of micro-Raman spectroscopy for the study of the atmospheric corrosion of copper alloys of cultural heritage (PhD), Vrije Universiteit, Brussel, 2006.

[37] D. Ghosh, B. Mondal, A.K. Das, Spectroscopy and dissociation of sulfuryl halides SO2X2 (X=F, Cl), Mol. Phys. 107 (2009) 1811-1816.

[38] J. Noh, S. Jang, D. Lee, K.S. Shin, Y.J. Ko, Eisuke Ito, S.W. Joo, Abnormal adsorption behavior of dimethyl disulfide on gold surfaces, Curr. Appl. Phys. 7 (2007) 605-610.

[39] J.K. Lim, L. . Kim, K.H. Kim, K. S. Shin, W. Kang J Choo, S.W. Joo, Adsorption of dimethyl sulfide and methanethiolate on Ag and Au surfaces: surface-enhanced Raman scattering and density functional theory calculation study, Chem. Phys. 330 (2006) 245-252.

[40] D. Bermejo, R. Escribano, J. Santos, The stimulated Raman spectrum of cyanogen, J. Mol. Spectrosc. 186 (1997) 144-154.

[41] M. Schwartz, C.H. Wang, Raman study of molecular motion in liquid phosphine, Chem. Phys, Lett. 25 (1974) 26-33.

[42] R.M.A. El Hinnawi, L. Peter, B. Meyer, Raman spectra of copper (I), silver (I) and gold (I) cyanides in aqueous solutions of sodium thiosulphate, J. Raman Spectrosc. 16 (1985) 272-279. 